\title{
EFEKTIVITAS EDUKASI DAN SIMULASI MANAJEMEN BENCANA TERHADAP KESIAPSIAGAANAN MENJADI RELAWAN BENCANA
}

\author{
Rahmania Ambarika \\ STIKes Surya Mitra Husada Kediri \\ Jalan Manila 37 Sumberece Kediri \\ E-mail :rahmania.ambar@gmail.com
}

\begin{abstract}
For Handling the initial disaster, volunteer efforts are needed to reduce the negative impact of the disaster. The low desire to become volunteers is caused by the lack of adequate knowledge about disaster volunteer. The process to be a volunteer is not easy because it involves cognitive processes in decision-making. The readiness of individuals to disaster volunteer demonstrated by their knowledge, skills and abilities acquired through education and learning. Preparation process to be disaster volunteer can be given through education and disaster simulation. The purpose of this research is to know the disaster management education and disaster simulation effect to the readiness become a disaster volunteer. This research design using Pra eksperimental approach one group pre - post test design. The population is 92 students in $8^{\text {th }}$ semester in ners program of STIKes Surya Mitra Husada Kediri and used purposive sampling technique, 50 respondents was taken with a purposive sampling. The results showed that readiness become a disaster volunteer before disaster management education is 37 respondents (74\%) most of the respondents in the category are not ready and after education is 44 respondents (88\%) . data analysis in this research used Wilcoxon test, and showed $p$ value $(0,000)$ showed that it has a relation between disaster management education and disaster simulation to the readiness become a disaster volunteer. Disaster management education can increase student motivation to participate to the disaster and this method is very successful.
\end{abstract}

\section{Keywords : disaster management education, simulation, readiness, disaster volunteer}

Abstrak : Penanganan awal bencana diperlukan upaya memberdayakan relawan bencana untuk mengurangi dampak negatif dari bencana. Masih rendahnya keinginan untuk menjadi relawan karena mereka tidak memiliki pengetahuan yang adekuat tentang kesiapan menjadi relawan bencana. Proses pertimbangan menjadi relawan bukanlah hal yang mudah karena melibatkan proses kongnitif dalam pengambilan keputusan. Kesiapan individu menjadi relawan bencana ditunjukkan oleh adanya pengetahuan, ketrampilan, dan kemampuan yang diperoleh melalui proses pendidikan dan belajar. Proses penanaman kesiapan menjadi relawan bencana dapat diberikan melalui pendidikan dan simulasi bencana. Tujuan penelitian ini adalah untuk mengetahui pengaruh edukasi dan simulasi manajemen bencana terhadap kesiapsiagaan menjadi relawan bencana pada mahasiswa. Desain penelitian ini menggunakan pendekatan pra eksperimental dengan desain one group pre - post test design. Populasinya adalah seluruh mahasiswa semester VIII Program Studi Pendidikan Ners STIKes Surya Mitra Husada Kediri sejumlah 92 mahasiswa dan melalui teknik Purposive Sampling didapatkan 50 responden. Hasil penelitian menunjukkan bahwa kesiapan menjadi relawan bencana sebelum dilakukan edukasi dan simulasi manajemen bencana sebagian besar responden dalam kategori tidak Siap adalah sebanyak 37 responden (74\%) dan sesudah diberikan simulasi adalah sebanyak 44 responden (88\%). Analisa data dengan uji statistik Wilcoxon, didapatkan $p$ value $=$ 0,000 artinya terdapat pengaruh edukasi dan simulasi manajemen bencana terhadap kesiapan menjadi relawan bencana. Edukasi dan simulasi manajemen bencana sebagai salah satu media terbaik untuk mempersiapkan mahasiswa menjadi relawan bencana karena melalui proses pembelajaran dengan dilakukan edukasi dan simulasi bencana dapat meningkatkan pengetahuan dan keterampilan serta kemampuan mahasiswa menjadi relawan bencana sehingga akan meningkatkan kesiapsiagaan menjadi relawan. Edukasi dan pelatihan bencana diperlukan untuk diterapkan di institusi sehingga semua mahasiswa memiliki kesiapsiagaan untuk menjadi relawan bencana karena bencana bisa datang sewaktu-waktu dan hal itu membutuhkan relawan bencana.

Kata Kunci : edukasi, simulasi, manajemen bencana, kesiapasiagaan, relawan bencana 


\section{PENDAHULUAN}

Bencana merupakan suatu kejadian yang mengganggu kehidupan normal. Penanganan yang segera atau cepat setelah kejadian sangat dibutuhkan untuk mengurangi dampak negatif dari bencana yang bisa menyebabkan kematian atau mengancam nyawa. Penanganan awal pada bencana diperlukan upaya memberdayakan relawan dan masyarakat itu sendiri untuk mengurangi dampak negatif dari bencana (Cahyono, 2014).

Dibutuhkan kesiapan masyarakat maupun tenaga kesehatan untuk menjadi relawan. Berdasarkan penelitian yang dilakukan Fung (2008), bahwa sebagian besar perawat tidak siap menjadi relawan karena mereka tidak tahu apa yang harus dipersiapkan untuk menjadi relawan bencana. Berdasarkan penelitian yang dilakukan Usher \& Mayner (2011), 63\% dari 39 institusi pendidikan didapatkan mahasiswa masih rendahnya keinginan untuk menjadi relawan.

Studi pendahuluan yang dilakukan oleh peneliti dengan wawancara didapatkan di kampus stikes Surya Mitra Husada Kediri hanya organisasi Badan Eksekutif Mahasiswa (BEM) yang sering menjadi relawan tetapi untuk keseluruhan mahasiswa semester VIII Program Studi Pendidikan Ners belum terlibat sebagai relawan bencana. Dari wawancara yang dilakukan pada 15 orang mahasiswa semester VIII didapati 6 orang mahasiswa bersedia atau siap menjadi relawan bencana dengan alasan mereka adanya rasa kemanusiaan dalam diri yang tinggi terhadap sesama, berempati pada korban bencana, peduli kepada sesama yang mengalami bencana, mereka juga memiliki rasa kemauan dan minat yang kuat untuk menjadi relawan bencana. Sedangkan 9 orang mahasiswa tidak siap menjadi relawan bencana dengan alasan mereka tidak memiliki pengetahuan dan ketrampilan menjadi relawan karena merasa tidak mampu menjadi relawan bencana dan juga ada perasaan takut dan malas karena menjadi relawan bencana dianggap sulit.

Proses pertimbangan menjadi relawan melibatkan proses kongnitif berupa pengambilan keputusan. Penilaian dan pengambilan keputusan digunakan untuk menyeleksi diantara pilihan-pilihan atau mengevaluasi kesempatankesempatan yang ada (Stenberg, 2013).

Mahasiswa Program Studi

Pendidikan Ners merupakan calon perawat yang akan berperan sebagai relawan dan pemberi pertolongan pada saat bencana bagi masyarakat. Oleh karena itu, penting bagi mahasiswa Program Studi Pendidikan Ners untuk memiliki pengetahuan kebencanaan yang adekuat serta kesiapan menjadi relawan bencana yang baik. Dengan pemberian edukasi dan simulasi manajemen bencana mahasiswa semester VIII akan mendapatkan tambahan pengetahuan seputar kesiapan menjadi relawan bencana.

Manfaat yang dapat diperoleh dengan diberikannyaedukasi dan simulasi bencana adalah meningkatkan pengetahuan dan kemampuan untuk menjadi relawan sehingga akan meningkatkan kesiapsiagaan mahasiswa khusunya keperawatan untuk menjadi relawan bencana. Harapannya seorang perawat akan siap kapan saja untuk menjadi relawan karena sudah dibekali pengetahuan tentang penanganan bencana.

\section{METODE PENELITIAN}

Desain penelitian ini menggunakan pendekatan pra eksperimental dengan desain one group pre-post test design. Penelitian dilakukan di STIKes Surya Mitra Husada Kediri pada tanggal 21 Maret sampai 26 Maret 2016. Populasinya adalah seluruh mahasiswa semester VIII Program Studi Pendidikan Ners STIKes Surya Mitra Husada Kediri berjumlah 92 dan melalui teknik Purposive Sampling yang memenuhi kriteria inklusi didapatkan 50 responden. Instrumen yang digunakan adalah lembar kuesioner, SAP, dan panduan role play dan simulasi. Variabel independen yang diteliti adalah edukasi dan simulasi manajemen bencana dan variabel dependen adalah kesiapan menjadi relawan bencana. 


\section{HASIL PENELITIAN}

Tabel 1. Karakteristik subyek

\begin{tabular}{|c|c|c|c|}
\hline No & Karakteristik & $\mathbf{N}$ & $\%$ \\
\hline \multirow[t]{4}{*}{1} & Usia (th) & & \\
\hline & $<20$ & 7 & 14 \\
\hline & $20-25$ & 25 & 50 \\
\hline & $>25$ & 18 & 36 \\
\hline \multirow[t]{3}{*}{2} & Jenis kelamin & & \\
\hline & Laki-laki & 31 & 62 \\
\hline & Perempuan & 19 & 38 \\
\hline \multirow[t]{4}{*}{3} & Tempat tinggal & & \\
\hline & Kost/kontrak & 42 & 84 \\
\hline & Ortu & 7 & 14 \\
\hline & Saudara dekat & 1 & 2 \\
\hline \multirow[t]{3}{*}{4} & Sumber biaya & & \\
\hline & Ortu & 48 & 96 \\
\hline & Saudara & 2 & 4 \\
\hline \multirow[t]{4}{*}{5} & Kesiapsiagaan & elun & \\
\hline & Tidak siap & 37 & 74 \\
\hline & Cukup siap & 9 & 18 \\
\hline & Siap & 4 & 8 \\
\hline \multirow[t]{5}{*}{6} & Kesiapsiagaan & lah) & \\
\hline & Tidak siap & 4 & \\
\hline & Cukup siap & 2 & 4 \\
\hline & Siap & 44 & 88 \\
\hline & Total & 50 & 100 \\
\hline
\end{tabular}

Berdasarkan Tabel 1 di atas diketahui dari 50 responden, setengah dari total responden adalah kelompok usia 20-25 tahun yaitu sebanyak 25 responden $(50 \%)$, jenis kelamin laki-laki yaitu sebanyak 31 responden (62\%), hampir seluruh responden bertempat tinggal di Kost/Kontrakan yaitu sebanyak 42 responden (84\%), dibiayai oleh orang tua sebanyak 48 responden (96\%), kesiapan menjadi relawan bencana sebelum dilakukan edukasi manajemen bencana dalam kategori tidak siap adalah sebanyak 37 responden (74\%) dan setelah dilakukan edukasi manajemen bencana hampir seluruh responden dalam kategori siap adalah sebanyak 44 responden $(88 \%)$.

Tabel 2 : Hasil Uji Statistik

\begin{tabular}{cc}
\hline Edukasi dan simulasi & Tingkat \\
Manajemen Bencana & Signifikansi \\
\hline Sebelum & 0.000 \\
Sesudah & 0.000 \\
\hline
\end{tabular}

Setelah dilakukan uji statistik dengan menggunakan Uji Wilcoxon, dengan nilai $\alpha=0,05$ didapat hasil $p$ value $=0,000(p<0,05)$ sehingga HO ditolak. Dengan demikian dapat disimpulkan bahwa terdapat pengaruh edukasi dan simulasi manajemen bencana terhadap kesiapan menjadi relawan bencana pada mahasiswa semester VIII Program Studi Pendidikan Ners STIKes Surya Mitra Husada Kediri.

\section{PEMBAHASAN}

Kesiapan Menjadi Relawan Bencana Sebelum Dilakukan Edukasi dan Simulasi Manajemen Bencana Pada Mahasiswa Semester VIII Program Studi Pendidikan Ners STIKes Surya Mitra Husada Kediri

Berdasarkan hasil penelitian diketahui bahwa kesiapsiagaan menjadi relawan bencana sebelum dilakukan edukasi dan simulasi manajemen bencana pada Mahasiswa Semester VIII Program Studi Pendidikan Ners STIKes Surya Mitra Husada Kediri yaitu sebagian besar responden berada dalam kategori tidak siap yaitu sebanyak 37 responden (74\%). $\mathrm{Hal}$ ini menunjukan bahwa alasan responden tidak siap menjadi relawan korban bencana oleh karena responden masih mempertimbangkan keputusan yang akan diambil dimana menjadi relawan bukan hal yang mudah. Di samping itu juga ada responden yang trauma terhadap kejadian bencana yang pernah dialami sebelumnya.

Proses pertimbangan menjadi relawan melibatkan proses kongnitif berupa pengambilan keputusan. Penilaian dan pengambilan keputusan digunakan untuk menyeleksi diantara pilihan-pilihan atau mengevaluasi kesempatankesempatan yang ada (Stenberg, 2013).

Pengambilan keputusan untuk menjadi relawan tidaklah mudah. Relawan menekankan pada nilai personal seperti kasih sayang pada orang lain, keinginan untuk menolong orang lain, membantu seseorang lepas dari kesulitan dan manfaat relawan bencana misalnya, rasa senang membantu korban bencana alam 
sebab dapat meringankan penderitaan orang lain, ada rasa bangga menjadi relawan, ada imbalan yang menguntungkan bagi pribadi relawan, dapat meningkatkan rasa percaya diri dan melatih diri untuk peduli dengan orang lain (Sears, 2012).

Relawan bukanlah suatu pekerjaan yang rutin karena tidak terjadi setiap waktu dan bersifat insidental. Banyak faktor yang mempengaruhi keinginan individu dewasa untuk menjadi relawan. Salah satu faktor yang mendorong adalah sikap yang lebih berfokus pada hubungannya dan keturunannya, misalnya seseorang menjadi relawan karena orang tuanya juga merupakan relawan. Karakteristik yang ada dalam sikap yang lebih berfokus pada hubungannya dan keturunannya adalah adanya sikap peduli, mengayomi dan mengatur (Stenberg, 2013).

Hasil kuesioner menunjukan bahwa menjadi relawan bencana membutuhkan kondisi fisik sehat atau tidak mengidap penyakit, serta perasaan takut dan cemas dan menjadi relawan merupakan hal yang sulit atau tantangan bagi diri sendiri untuk membantu orang lain. Perasaan cemas dan takut didasari oleh kurangnya kesiapan untuk menjadi relawan karena kurangnya pengetahuan dan ketrampilan untuk menjadi relawan padahal seorang perawat memiliki tugas dan tanggung jawab ketika terjadi bencana salah satuya harus siap menjadi relawan bencana yang siap ditugaskan kapan saja dan dimana saja ketika menjadi bencana.

\section{Kesiapan Menjadi Relawan Bencana Setelah Dilakukan Edukasi Manajemen Bencana Pada Mahasiswa Semester VIII Program Studi Pendidikan Ners STIKes Surya Mitra Husada Kediri}

Edukasi dengan tehnik pemberian informasi dan simulasi manajemen bencana merupakan salah satu media terbaik untuk mempersiapkan mahasiswa menjadi relawan bencana. Hampir seluruh mahasiswa dalam kategori siap untuk membantu korban bencana adalah sebanyak 44 responden (88\%). Hal ini menunjukan bahwa edukasi manajemen bencana merupakan metode yang tepat dalam merubah sikap dan perilaku responden untuk menjadi seorang relawan. Pengetahuan, informasi dan cara penanggulangan bencana yang diberikan peneliti melalui pemberian informasi dan role play simulasi bencana dapat meningkatkan pengetahuan, ketrampilan dan kemampuan responden dalam penanggulangan bencana serta meningkatkan motivasi untuk menjadi relawan.

Setelah mendapatkan edukasi dan simulasi manajemen bencana responden merasa empati dan ingin dapat terjun langsung membantu korban bencana. Oleh Karena itu fungsi edukasi dan simulasi manajemen bencana sebagai salah satu media terbaik untuk mempersiapkan mahasiswa terhadap bencana.

Pada pendidikan bencana tingkat kesiapan menjadi relawan bencana akan didiskusikan untuk kemudian ditingkatkan melalui proses pembelajaran kemudian dilakukan roleplay simulasi bencana untuk lebih meningkatkan kesiapan menjadi relawan. Kesiapan individu untuk menjadi relawan bencana juga ditunjukkan oleh adanya pengetahuan, ketrampilan, dan kemampuan yang diperoleh melalui proses pendidikan dan belajar (Clust, 2012).

Manajemen bencana didefinisikan sebagai serangkaian upaya yang meliputi penetapan kebijakan pembangunan yang berisiko timbulnya bencana, kegiatan pencegahan bencana, tanggap darurat, rehabilitasi dan rekonstruksi (UU No. 24 Tahun 2007). Manajemen bencana dirumuskan sebelum bencana terjadi. Siklus manajemen bencana diawali dengan kegiatan sebelum terjadinya bencana yang meliputi kegiatan mitigasi (mengurangi dampak dari bencana) dan kesiapsiagaan (preparedness). Saat bencana terjadi dilakukan kegiatan tanggap darurat (emergency response) dan selanjutya adalah kegiatan rekonstruksi.

Berdasarkan hasil penelitian diketahui bahwa hampir seluruh responden baik laki-laki maupun perempuan siap untuk terjun langsung 
menolong korban bencana. Informasi dan pengetahuan yang diberikan peneliti melalui edukasi dan simulasi manajemen bencana dapat menjadi bekal untuk meningkatkan kesiapan mahasiswa. Mahasiswa keperawatan lebih paham dengan persiapan untuk menjadi relawan seperti disaster Kit (P3K) , kotak, set luka, obat-obatan, handphone, alat pemadam api, nomor telepon darurat (polisi, pemadam kebakaran). Dengan diberikannya roleplay simulasi bencana, mahasiswa keperawatan diperlihatkan secara langsung kondisi bencana sehingga meningkatkan pengetahuan yang berdampak positik meningkatkan kesiapsiagaan mahasiswa keperawatan untuk menjadi relawan bencana.

\section{Pengaruh Edukasi dan Simulasi Manajemen Bencana Terhadap Kesiapan Menjadi Relawan Bencana Pada Mahasiswa Semester VIII Program Studi Pendidikan Ners STIKes Surya Mitra Husada Kediri}

Setelah dilakukan uji statistik dengan menggunakan Uji Wilcoxon, dengan nilai $\alpha=0,05$ didapat hasil $p$ value $=0,000(p<0,05)$ sehingga $\mathrm{H} 0$ ditolak dan $\mathrm{H} 1$ diterima. Dengan demikian ada pengaruh edukasi dan simulasi manajemen bencana terhadap kesiapan menjadi relawan bencana pada mahasiswa semester VIII Program Studi Pendidikan Ners STIKes Surya Mitra Husada Kediri.

Perbedaan antara sebelum dan sesudah diberikan edukasi dan simulasi manajemen bencana diketahui bahwa sebelum peneliti melakukan edukasi dan simulasi manajemen bencana mahasiswa merasa tidak siap oleh karena disebabkan perasaan cemas, takut, kesibukan di luar aktivitas kuliah bahkan menciptakan banyak alasan untuk tidak menjadi seorang relawan bencana. Akan tetapi setelah peneliti memberikan edukasi dan simulasi manajemen bencana diketahui bahwa hampir seluruh mahasiswa merasa mempunyai bekal pengetahuan yang baik bahkan timbul rasa simpati dan empati untuk dapat terjun langsung menolong korban bencana.
Berdasarkan hasil penelitian diketahui bahwa kesiapan mahasiswa untuk menjadi relawan bencana sebelum diberikan edukasi dan simulasi tentang manajemen bencana yaitu sebesar 37 responden (74\%) masih mempertimbangkan keputusan yang akan diambil oleh karena menjadi relawan bukan hal yang mudah. Edukasi dan simulasi manajemen bencana merupakan metode yang sangat bagus dan merupakan salah satu media terbaik untuk mempersiapkan mahasiswa keperawatan menjadi relawan bencana sehingga mengurangi permasalahan kurangnya relawan bencana dari tenaga kesehatan karena mahasiswa sudah dibekali ilmu dan pengetahuan yang akan meningkatkan kemampuan perawat menjadi relawan bencana.

\section{KESIMPULAN DAN SARAN}

\section{Kesimpulan}

1. Kesiapan menjadi relawan bencana sebelum dilakukan edukasi dan simulasi manajemen bencana pada mahasiswa semester VIII Program Studi Pendidikan Ners STIKes Surya Mitra Husada Kediri yaitu sebagian besar responden dalam kategori tidak siap yaitu sebanyak 37 responden (74\%).

2. Kesiapan menjadi relawan bencana setelah dilakukan edukasi dan simulasi manajemen bencana pada mahasiswa semester VIII Program Studi Pendidikan Ners STIKes Surya Mitra Husada Kediri yaitu hampir seluruh responden dalam kategori siap adalah sebanyak 44 responden (88\%).

3. Setelah dilakukan uji statistik dengan menggunakan Uji Wilcoxon, dengan nilai $\alpha=0,05$ didapat hasil $p$ value $=$ $0,000(p<0,05)$ sehingga HO ditolak dan $\mathrm{H} 1$ diterima. Dengan demikian ada pengaruh edukasi manajemen bencana terhadap kesiapan menjadi relawan bencana pada mahasiswa semester VIII Program Studi Pendidikan Ners STIKes Surya Mitra Husada Kediri. 


\section{Saran}

1. Bagi Mahasiswa Program Studi Pendidikan Ners Semester VIII

Diharapkan penelitian ini bermanfaat bagi mahasiswa Program Studi Pendidikan Ners untuk memperoleh informasi tentang manajemen bencana terhadap kesiapan menjadi relawan pada mahasiswa terhadap risiko bencana di kampus STIKes Surya Mitra Husada Kediri terutama Program Studi Pendidikan Ners semester VIII.

2. Bagi Program Studi Pendidikan Ners dan STIKes

\section{DAFTAR PUSTAKA}

A. Aziz, Alimul Hidayat. 2010. Metode Penelitian Keperawatan Dan Teknik Analisis Data. Jakarta : Penerbit. Salemba Medika.

Clust, Michael, R.J.Human,dan D.M.Simpson.(2007).Mapping and rail safety: the development of mapping display technology for data communication. Center for Hazards Research and Policy Development.

Dalyono, 2005. Psikologi Pendidikan. Jakarta: Rineka Cipta.

Darwis, S. D. 2010. Metode Penelitian. Jakarta : EGC.

Djamarah, 2012. Strategi Belajar Mengajar. Cetakan Keempat. Jakarta: Penerbit Rineka Cipta.

Forum Keperawatan Bencana, 2014. Keperawatan bencana. Banda Aceh: PMI dan JRCS.

Hatimah, I. 2013. Strategi Dan Metode Pembelajaran. Bandung: Andira.

Hamalik, Oemar. 2012. Proses Belajar Mengajar, Jakarta: PT Bumi Aksara.

Notoatmodjo, Soekidjo. 2010, Pendidikan dan Perilaku Kesehatan. Jakarta : Rineka Cipta.
Diharapkan penelitian ini bermanfaat bagi Program Studi Pendidikan Ners dan STIKes Surya Mitra Husada Kediri untuk memperoleh informasi mengenai edukasi manajemen bencana terhadap kesiapan menjadi relawan bencana pada mahasiswa di kampus STIKes Surya Mitra Husada, terutama Program Studi Pendidikan Ners sehingga dapat menindaklanjuti penyediaan edukasi dan adanya pelatihan manajemen bencana dan kesiapan menjadi relawan bencana di lingkungan kampus.
Nursalam, 2012. Konsep dan Penerapan Metodologi Penelitian IImu Keperawatan. Jakarta : Salemba Medika.

Sugiyono, 2011. Metode Penelitian Kuantitatif Kualitatif Dan R\&D (Edisi Revisi). Bandung : CV. Alfabeta.

Rohani, A. 2010. Pengelolaan Pengajaran Sebuah Pengantar Menuju Guru Profesional.Jakarta: Rineka Cipta.

Slamet, M. 2012. Voluntary Organization. margonoipb. files. wordpress. com/2009/03/8. volunteersm. ppt.

Stenberg, J.R. 2014. The concept of creativity: prospect and paradigms. Handbook of creativity. Cambridge: University press.

Santamaria,Barbara.2009. Community Health Nursing Theory \& Practice. Newjersey: Pearson Education.

Slameto, 2013. Belajar Dan Faktor-Faktor Yang Mempengaruhi. Jakarta: Rineka Cipta.

Usher, kim dan Lidia Mayner. 2011. Disaster nursing: a descriptive survey of australian undergraduate nursing curricula Australasian Emergency Nursing Journal,14,1-5. 